\title{
The Effects of Dementia Knowledge on Job Satisfaction of Care Workers : Testing the Mediating Effects of Caring Behavior
}

\author{
Eun-Young $\mathrm{Yu}^{1}$, Jea-Ug Ko ${ }^{2}$ \\ ${ }^{1}$ Ph.D.student, Dept. of Social Welfare, Catholic Kwandong University, Korea, gio999@naver.com \\ ${ }^{2}$ Professor, Dept. of Social Welfare, Catholic Kwandong University, Korea, kojea62@cku.ac.kr
}

Corresponding author: Jea-Ug Ko

\begin{abstract}
Korea has entered an aging society as its average life expectancy increased, and by 2026, it will enter a super-aged society. The aging population has also increased rapidly, and the burden of caring for the elderly with senile diseases such as dementia and stroke is bound to increase, and the role of family members and caregivers is paramount. This study aimed to analyze dementia knowledge and its effects on the caring behavior and job satisfaction of care workers in charge of dementia patients. Data were collected from 346 care workers from December 1 to 30, 2020. Data were processed through frequency analysis, descriptive statistics, and correlation analysis by using an SPSS ver. 23.0 program. Simple and multiple regression analyses and three-step mediating effect analysis were performed to test the hypotheses. This study found that dementia knowledge affected caring behavior, dementia knowledge and caring behavior affected job satisfaction, and caring behavior had mediating effects on dementia knowledge on job satisfaction. The results of the study is intended to improve the quality of long-term care insurance services for the elderly and establish a stable long-term care insurance system for the elderly by introducing effective education methods and maintaining education.
\end{abstract}

Keywords: Dementia Knowledge, Caring Behavior, Job Satisfaction, Control Variable

\section{Introduction}

With a longer average life expectancy, South Korea has entered an aged society with more than $15.7 \%$ of the total population aged $\geq 65$ years since 2020 and is expected to become a super-aged society in 2026[1]. With the rapid increase in the population with dementia, the number of dementia patients aged $\geq 65$ has reached to approximately 870,000 as of 2020 and can exceed one million by 2024 [2]. Such increase in the population with dementia has led to the rising need care workers for elderly with geriatric diseases, including dementia and palsy, [3] and the government has run the longterm care insurance system since July 2008 to give national-level support to the elderly who are unable to lead a daily life independently and relieve the caregiving burden from their families[4]. This has led to a change from family care in complete charge of elderly care to professional caregiving service in national charge[5] and made care workers give long-term care service to seniors having difficulty leading their daily lives independently[6]. As the rapid increase in the elderly population and the population with dementia has led to the continuous increase in the demand for elderly care and further

Received: August 07, 2021; $1^{\text {st }}$ Review Result: September 24, 2021; $2^{\text {nd }}$ Review Result: November 15, 2021 Accepted: December 31, 2021 
diversification of the social needs for high-quality care service, it is necessary to cultivate and place a professional workforce[7] to give more professional, high-quality service.

Dementia means deteriorated brain functions due to a temperamental lesion in the brain, involves loss of memory, orientation, judgment, problem-solving ability, and verbal functions, disturbing daily social life and impairing several cognitive functions, is unlikely to be cured once it develops, and makes it challenging to lead even basic daily life, causing heavier dependence on family or society than other geriatric diseases[8]. In addition, as a progression of dementia lowers the cognitive functions constantly, making communication difficult, mental and behavioral symptoms, such as delusion, roaming, and aggression[9], bring physically and emotionally adverse outcomes to the patients and those around them or exert serious effects and increase the burden of caregiving for the elderly with dementia[10]. It is urgent to manage care workers in charge of the elderly with dementia and make qualitative improvement, and it is essential to give necessary support to care workers for them to become satisfied with their job. Unless care workers are fully satisfied with their job, their caring behavior and their service quality can deteriorate[11]; therefore, their sense of job satisfaction is crucial in making qualitative improvement in long-term care service for the elderly. As the social demand for the qualitative improvement in caregiving service[12] is on a gradual increase, the level of knowledge for care workers, who form critical workforce for long-term care insurance, is a common task with social responsibilities, not a personal issue[13]. In particular, dementia knowledge can directly affect the elderly with dementia, who require others' assistance, and needs to be considered an important issue for care workers' caring behavior[14]. In other words, even the elderly with dementia have the right to be given high-quality care, and care workers are obliged to acquire a complete knowledge about dementia and give high-quality care to the elderly with dementia[15]; the better the knowledge about dementia, the more positive the attitude toward the condition[16] and the knowledge of dementia obtained through specialized dementia education also affects job satisfaction and work efficacy[16].

Care workers' experiences of caregiving may differ in job performance, and noted that those having given care to seniors with dementia showed a higher level of caring behavior, implying that the experiences of caregiving accumulate knowledge and skills and, consequently, improve the behavior of caring for dementia patients in terms of coping with abnormal behaviors and daily living management[17]. Suppose more experiences and knowledge lead to a higher level of caring behavior, making an institutional device that allows experienced care workers with much knowledge about dementia to take complete charge of the elderly with dementia. In this line, giving information and knowledge to care workers is expected to help in providing high-quality care and improve the quality of life for the elderly with dementia. Satisfaction of care workers in charge of the elderly with dementia feel that their current job can affect the quality of their own life and significantly affect caregiving service for the elderly with dementia; that is, high-quality caregiving service depends on job satisfaction that enables the efficient and positive performance of a job given to individuals, and the outcome of job satisfaction is expected to enhance job performance and contribute to the improvement in the quality of care, implying that job satisfaction can make dementia patients more satisfied[18]. Also, it was confirmed that the quality of dementia-related caregiving service given by care workers cannot simply meet the physical needs but promote expertise in dementia and perception of relevant skills, implying that they can relieve the burden of caregiving work, feel self-confident and worthy, and become more satisfied with their job. In this context, since job satisfaction of care workers, who form manpower to give personal service to the elderly with dementia, is vital in terms of the quality of care[18], the long-term care insurance system characterized by the heavy dependence on human resources requires improving job satisfaction, which arouses positive behaviors among care workers. Many studies have been conducted on the effects of caregiving's burden on the quality of care in families of dementia patients. Some researchers investigated the association between the 
burden of dementia-related caregiving and job satisfaction in nursing staffing for dementia patients[19]. In contrast, little research has been conducted on care workers giving the most personal care as the critical resource for the long-term care insurance system.

It is necessary to establish the importance of care workers' roles as service providers and perception as professional manpower, give vocational education in advance, and improve functional and technical caring competence. This study aimed to determine the level of dementia knowledge of care workers, see if dementia knowledge affects job satisfaction, and determine if caring behavior has any mediating effect on the association between dementia knowledge and job satisfaction. It is also intended to present a direction for improving care workers' knowledge about dementia, their caring competence and job satisfaction, and contribute to the qualitative improvement of long-term care insurance service.

\section{Methods}

\subsection{Research model}

The research model consisted of dementia knowledge as an independent variable, care performance parameter, and job satisfaction as dependent variables.

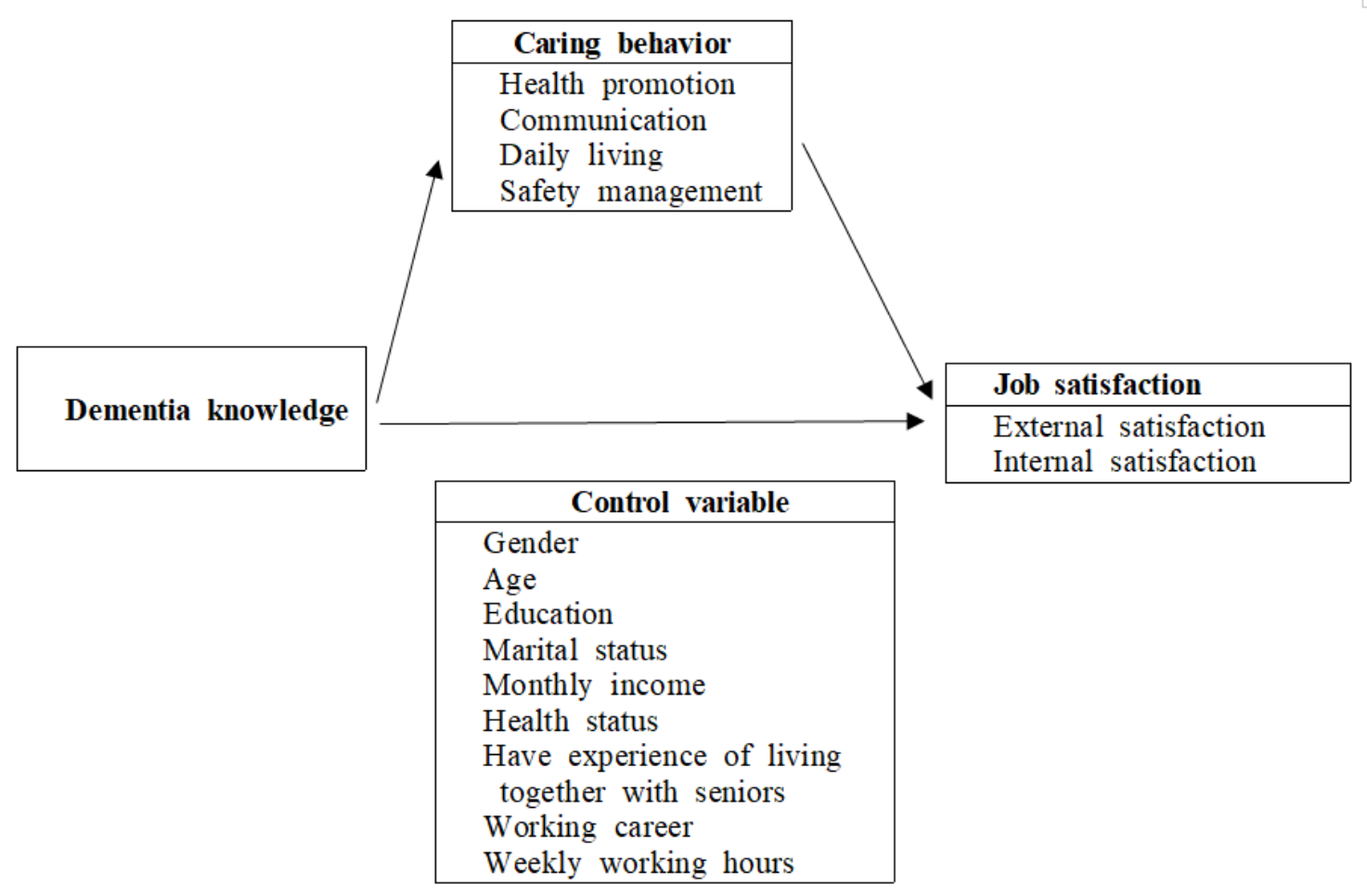

[Fig. 1] Research Model

\subsection{Hypotheses}

First, dementia knowledge would affect caring behavior.

Second, dementia knowledge would affect job satisfaction.

Third, caring behavior would affect job satisfaction. 
Fourth, caring behavior would have mediating effects on the impact of dementia knowledge on job satisfaction.

\subsection{Subjects}

This study was conducted in care workers who were giving long-term care service through longterm care facilities and home-based welfare centers in K City and D Region, understood the purpose and purport of the study, and spontaneously gave written consent to the participation. A total of 360 questionnaires were distributed, and 351 copies were returned; then, a total of 344 copies were finally analyzed, with 341 women and 3 men participating, excepting 7 poorly completed. For data collection, prior consent was obtained from the chiefs of 10 long-term care facilities and 10 home-based welfare centers in K City and D Region from December 1 to 30, 2020; then, first-grade care workers who had given care to seniors with dementia for at least 3 months were given explanation about the need, purpose, and contents of the study and were asked to give written consent to the participation at their will and complete a structured questionnaire, which required about 20 to 30 minutes.

\subsection{Instruments}

\subsubsection{Dementia Knowledge}

The scale Hwang (1999) used to determine the level of dementia knowledge in people giving care to the elderly with dementia was used to measure dementia knowledge. This scale has a total of 20 items: 10 for knowledge about dementia as a disease, 3 for knowledge about dementia treatment, and 7 for knowledge about dementia nursing. A correct answer was scored 1 and a wrong one 0 , with a higher score meaning better dementia knowledge.

\subsubsection{Caring Behavior}

The scale developed by Hwang and Jang (1999) to measure dementia knowledge, attitude, and caregiving activity in caregivers for the elderly with dementia and revised by Park and Kim was used to measure caring behavior. While previous research divided sub-variables into effective communication, coping with abnormal behavior, safety promotion, stimulation and activation, physical health promotion, and daily activity function maintenance, this study did not divide subconcepts. A five-point Likert scale was used to score 5 for totally agree, 4 for agree, 3 for average, 2 for disagree, and 1 for totally disagree, with a higher score meaning better caring behavior.

\subsubsection{Job Satisfaction}

The instrument developed for such sub-variables as internal satisfaction $(2,3,4,5,6,11$, and 15) and external satisfaction $(1,7,8,9,10,12,13$, and 14) by Choi (2017) based on the previous research was used to measure job satisfaction. This five-point scale with a total of 15 items was used to score 1 for totally disagree, 2 for disagree, 3 for average, 4 for agree, and 5 for totally agree, with a higher score meaning a higher level of job satisfaction.

\subsection{Reliability}

The factor analysis of job satisfaction drew two factors. Total variation description of the factors was estimated at $63.155 \%$, with factor loading at $\geq 0.5$ for each factor, which was statistically significant with $\mathrm{KMO}=0.941$ and $\chi^{2}=3453.938$; therefore, the results of the factor analysis of job 
satisfaction were appropriate. The reliability test found that it was reliable, with Cronbach's alpha of 0.853-0.929. Such factor orders as internal satisfaction and external satisfaction were used for analysis.

[Table 1] Test of Job Satisfaction for Validity and Reliability

\begin{tabular}{c|c|c|c|c|c|c} 
Factor & Item & Factor loading & Eigenvalue & Variable & $\begin{array}{c}\text { Cumulative } \\
\text { variable }\end{array}$ & Cronbach's alpha \\
\hline \multirow{5}{*}{ Internal } & Satisfied 2 & .844 & & & & \\
& Satisfied 1 & .802 & & & & \\
& Satisfied 3 & .788 & & & & \\
& Satisfied 5 & .749 & & & \\
& Satisfied 4 & .749 & 5.487 & 36.583 & & \\
& Satisfied 7 & .685 & & & \\
& Satisfied 11 & .635 & & & \\
& Satisfied 6 & .624 & & & \\
& Satisfied 15 & .584 & & & \\
\hline \multirow{5}{*}{ External } & Satisfied 13 & .822 & & & \\
& Satisfied 14 & .725 & & & \\
& Satisfied 12 & .677 & & & \\
& Satisfied 8 & .628 & 3.986 & 26.572 & & \\
& Satisfied 10 & .603 & & & \\
& Satisfied 9 & .582 & & & \\
\hline
\end{tabular}

The factor analysis of caring behavior drew four factors. Total variation description of the factors was estimated at $60.834 \%$, with factor loading at $\geq 0.5$ for each factor, which was statistically significant with $\mathrm{KMO}=0.932$ and $\chi^{2}=4470.374$; therefore, the results of the factor analysis of caring behavior were appropriate. The reliability test found that it was reliable, with Cronbach's alpha of 0.782-0.903. Such factor orders as health promotion, communication, daily living, and safety management were used for analysis.

[Table 2] Test of Caring Behavior for Validity and Reliability

\begin{tabular}{c|c|c|c|c|c|c}
\hline \multicolumn{1}{c|}{ Factor } & Item & Factor loading & Eigenvalue & Variable & $\begin{array}{c}\text { Cumulative } \\
\text { variable }\end{array}$ & Cronbach's alpha \\
\hline & Performed 19 & .700 & & & & \\
& Performed 15 & .698 & & & \\
Performed 20 & .688 & & & \\
Health promotion & Performed 16 & .683 & & & \\
& Performed 14 & .677 & & & \\
& Performed 17 & .673 & 4.717 & 21.866 & 21.866 & \\
& Performed 21 & .648 & & & \\
& Performed 22 & .584 & & & \\
& Performed 23 & .520 & & & \\
& Performed 18 & .478 & & & & \\
\hline
\end{tabular}




\begin{tabular}{|c|c|c|c|c|c|c|}
\hline & $\begin{array}{l}\text { Performed } 1 \\
\text { Performed } 3 \\
\text { Performed } 2 \\
\text { Performed } 5\end{array}$ & $\begin{array}{l}.701 \\
.685 \\
.630 \\
.585 \\
\end{array}$ & & & & \\
\hline Daily living & $\begin{array}{l}\text { Performed } 25 \\
\text { Performed } 27 \\
\text { Performed } 26 \\
\text { Performed } 24\end{array}$ & $\begin{array}{l}.753 \\
.748 \\
.713 \\
.545 \\
\end{array}$ & 2.860 & 13.442 & 50.307 & .782 \\
\hline $\begin{array}{c}\text { Safety } \\
\text { management }\end{array}$ & \begin{tabular}{|} 
Performed 7 \\
Performed 8 \\
Performed 12 \\
Performed 9 \\
Performed 11 \\
Performed 10
\end{tabular} & $\begin{array}{l}.754 \\
.753 \\
.712 \\
.606 \\
.602 \\
.509\end{array}$ & 2.382 & 10.527 & 60.834 & .809 \\
\hline
\end{tabular}

$\mathrm{KMO}=.932, \quad \mathrm{x}^{2}=4470.374, \mathrm{df}=300, \mathrm{p}=.000$

\subsection{Data Processing and Analysis}

The data were coded and statistically processed using SPSS ver 23.0. The frequency analysis was performed for the sample's demographic factors, while factor analysis and Cronbach's alpha were used to test the validity and reliability variables. Descriptive statistics and correlation analysis of the variables were used, and simple and multiple regression analysis and three-step mediating effect analysis were performed to test hypotheses.

\section{Results}

\subsection{Analysis of Participants' Socio-demographic Characteristics}

For the participants' socio-demographic characteristics, $99.1 \%$ were female, and $0.9 \%$ were male, whereas the most frequent age group was the $60 \mathrm{~s}(42.4 \%)$, followed by the $50 \mathrm{~s}$ and $\leq 40 \mathrm{~s}$. The most frequent education group was high school graduation $(50.6 \%)$, followed by middle school, elementary school, and college graduation; the most frequent marital status was married (75.6\%), followed by bereaved, unmarried, and divorced. The most recurring monthly income was 1.01 million to 2 million won $(51.2 \%)$, followed by $\geq 2.01$ million won and $\leq 1$ million won. The most frequent health status was good $(78.8 \%$ ), followed by very good and poor. $73.0 \%$ had the experience of living together with a senior, and $27.0 \%$ had no such experience. The most frequent working career was $1-<3$ years $(38.4 \%)$, followed by $5-<9$ years, $3-<5$ years, $\geq 10$ years, and $\leq 1$ year. The most frequent number of weekly working hours was $21-40(62.2 \%)$, followed by $\leq 20$ and $\geq 40$; the most frequent number of seniors in charge was $2(55.5 \%)$, followed by 3 and 1 ; and, currently, $51.2 \%$ were giving care to a senior with dementia, and $48.8 \%$ were giving no such care.

[Table 3] Demographic Factors of Sample

\begin{tabular}{c|c|c|c}
\hline \multicolumn{2}{c|}{ Division } & Frequency & $\%$ \\
\hline \multirow{2}{*}{ Gender } & $\mathrm{F}$ & 341 & 99.1 \\
& $\mathrm{M}$ & 3 & 9 \\
\hline \multirow{2}{*}{ Age } & $\leq 40 \mathrm{~s}$ & 66 & 19.2 \\
& $50 \mathrm{~s}$ & 132 & 38.4 \\
\hline
\end{tabular}




\begin{tabular}{|c|c|c|c|}
\hline & $\geq 60 \mathrm{~s}$ & 146 & 42.4 \\
\hline \multirow{4}{*}{ Education } & Elementary school & 28 & 8.1 \\
\hline & Middle school & 137 & 39.8 \\
\hline & High school & 174 & 50.6 \\
\hline & College & 5 & 1.5 \\
\hline \multirow{5}{*}{ Marital status } & Unmarried & 23 & 6.7 \\
\hline & Married & 260 & 75.6 \\
\hline & Bereaved & 44 & 12.8 \\
\hline & Divorced & 17 & 4.9 \\
\hline & $\leq 1$ & 53 & 15.4 \\
\hline \multirow[t]{2}{*}{ Monthly income (million won) } & $1.01-2$ & 176 & 51.2 \\
\hline & $\geq 2.01$ & 115 & 33.4 \\
\hline \multirow{3}{*}{ Health status } & Very good & 47 & 13.7 \\
\hline & Good & 271 & 78.8 \\
\hline & Poor & 26 & 7.6 \\
\hline \multirow{2}{*}{$\begin{array}{l}\text { Have experience of living } \\
\text { together with senior }\end{array}$} & Yes & 251 & 73.0 \\
\hline & No & 93 & 27.0 \\
\hline \multirow{5}{*}{ Working career (yrs) } & $\leq 1$ & 17 & 4.9 \\
\hline & $1-<3$ & 132 & 38.4 \\
\hline & $3-<5$ & 84 & 24.4 \\
\hline & $5-<9$ & 87 & 25.3 \\
\hline & $\geq 10$ & 24 & 7.0 \\
\hline \multirow{3}{*}{ Weekly working hours } & $\leq 20$ & 74 & 21.5 \\
\hline & $21-40$ & 214 & 62.2 \\
\hline & $\geq 40$ & 56 & 16.3 \\
\hline \multirow{3}{*}{ Number of seniors in charge } & 1 & 76 & 22.1 \\
\hline & 2 & 191 & 55.5 \\
\hline & 3 & 77 & 22.4 \\
\hline \multirow{2}{*}{$\begin{array}{l}\text { Currently giving care to seniors } \\
\text { with dementia }\end{array}$} & Yes & 176 & 51.2 \\
\hline & No & 168 & 48.8 \\
\hline \multicolumn{2}{|c|}{ Total } & 344 & 100.0 \\
\hline
\end{tabular}

\subsection{Descriptive Statistics and Correlation Analysis of Variables}

[Table 4] Descriptive Statistics of Variables

\begin{tabular}{|c|c|c|c|c|c|c|}
\hline \multicolumn{2}{|c|}{ Division } & $\mathrm{N}$ & Mean & $\mathrm{SD}$ & Skewness & Kurtosis \\
\hline \multicolumn{2}{|c|}{ Dementia knowledge } & 344 & 16.76 & 2.42 & -.94 & 1.17 \\
\hline \multirow{2}{*}{ Job satisfaction } & $\begin{array}{c}\text { Internal } \\
\text { satisfaction }\end{array}$ & 344 & 3.64 & .71 & -.51 & 1.07 \\
\hline & $\begin{array}{c}\text { External } \\
\text { satisfaction }\end{array}$ & 344 & 3.32 & .70 & -.14 & .54 \\
\hline \multirow{4}{*}{ Caring behavior } & Communication & 344 & 4.03 & .58 & -1.09 & 4.37 \\
\hline & $\begin{array}{c}\text { Safety } \\
\text { management }\end{array}$ & 344 & 3.94 & .58 & -.72 & 2.37 \\
\hline & Health promotion & 344 & 4.06 & .55 & -1.18 & 5.00 \\
\hline & Daily living & 344 & 3.95 & .61 & -.79 & 2.45 \\
\hline
\end{tabular}


The variables' descriptive statistics found that they scored 16.76 for dementia knowledge and 3.64 for internal satisfaction, and 3.32 for external satisfaction in terms of job satisfaction. For caring behavior, they scored highest for health promotion (4.06), followed by communication, daily living, and safety management. Normality was secured for the variables, with skewness within \pm 3.0 and kurtosis within \pm 10.0 .

[Table 5] Correlation Analysis of Variables

\begin{tabular}{|c|c|c|c|c|c|c|c|}
\hline Division & $\begin{array}{c}\text { Dementia } \\
\text { knowledge }\end{array}$ & $\begin{array}{c}\text { Internal } \\
\text { satisfaction }\end{array}$ & $\begin{array}{c}\text { External } \\
\text { satisfaction }\end{array}$ & $\begin{array}{c}\text { Communicatio } \\
\mathrm{n}\end{array}$ & $\begin{array}{c}\text { Safety } \\
\text { management }\end{array}$ & $\begin{array}{c}\text { Health } \\
\text { promotion }\end{array}$ & Daily living \\
\hline $\begin{array}{c}\text { Dementia } \\
\text { knowledge }\end{array}$ & 1 & & & & & & \\
\hline $\begin{array}{l}\text { Internal } \\
\text { satisfaction }\end{array}$ & $.187 * * *$ & 1 & & & & & \\
\hline $\begin{array}{c}\text { External } \\
\text { satisfaction }\end{array}$ & $.112 *$ & $.766^{* * * *}$ & 1 & & & & \\
\hline Communication & $.180^{* *}$ & $.298 * * *$ & $.227 * * *$ & 1 & & & \\
\hline $\begin{array}{c}\text { Safety } \\
\text { management }\end{array}$ & $.201 * * *$ & $.234 * * *$ & $.171 * *$ & $.723 * * *$ & 1 & & \\
\hline Health promotion & $.187 * * *$ & $.276^{* * * *}$ & $.225^{* * *}$ & $.585 * * *$ & $.633 * * *$ & 1 & \\
\hline Daily living & $.123^{*}$ & $.219 * * *$ & $.158 * *$ & $.522 * * *$ & $.546 * * *$ & $.645^{* * *}$ & 1 \\
\hline
\end{tabular}

$* \mathrm{p}<.05, * * \mathrm{p}<.01, * * * \mathrm{p}<.001$

The correlation analysis of the variables found that a statistically significant positive correlation was found among all the sub-variables of dementia knowledge, job satisfaction, and caring behavior. This is consistent with the research direction set by the researcher.

\subsection{Test for Effects of Dementia Knowledge on Caring Behavior}

[Table 6] Effects of Dementia Knowledge on Caring Behavior

\begin{tabular}{|c|c|c|c|c|c|c|c|c|}
\hline \multirow{2}{*}{$\begin{array}{l}\text { Dependent } \\
\text { variable }\end{array}$} & \multirow{2}{*}{$\begin{array}{l}\text { Independent } \\
\text { variable }\end{array}$} & \multicolumn{2}{|c|}{ Non-standardized coefficient } & \multirow{2}{*}{\begin{tabular}{|c|}
$\begin{array}{c}\text { Standardized } \\
\text { coefficient }\end{array}$ \\
Beta
\end{tabular}} & \multirow{2}{*}{ R Square } & \multirow{2}{*}{$\mathrm{F}$} & \multirow{2}{*}{$\mathrm{t}$} & \multirow{2}{*}{$\mathrm{p}$} \\
\hline & & $\mathrm{B}$ & Standard error & & & & & \\
\hline \multirow{2}{*}{$\begin{array}{c}\text { Communicati } \\
\text { on }\end{array}$} & (Constant) & 3.305 & .216 & & \multirow[b]{2}{*}{.132} & \multirow[b]{2}{*}{$11.408 * *$} & 15.297 & .000 \\
\hline & $\begin{array}{c}\text { Dementia } \\
\text { knowledge }\end{array}$ & .043 & .013 & .180 & & & $3.378 * *$ & .001 \\
\hline \multirow{2}{*}{$\begin{array}{c}\text { Safety } \\
\text { management }\end{array}$} & (Constant) & 3.132 & .214 & & \multirow[b]{2}{*}{.141} & \multirow[b]{2}{*}{$14.472 * * *$} & 14.603 & .000 \\
\hline & $\begin{array}{c}\text { Dementia } \\
\text { knowledge }\end{array}$ & .048 & .013 & .201 & & & $3.804 * * *$ & .000 \\
\hline \multirow{2}{*}{$\begin{array}{l}\text { Health } \\
\text { promotion }\end{array}$} & (Constant) & 3.346 & .204 & & \multirow[b]{2}{*}{.135} & \multirow[b]{2}{*}{$12.382 * * *$} & 16.425 & .000 \\
\hline & $\begin{array}{c}\text { Dementia } \\
\text { knowledge }\end{array}$ & .042 & .012 & .187 & & & $3.519 * * *$ & .000 \\
\hline \multirow[b]{2}{*}{ Daily living } & (Constant) & 3.427 & .228 & & \multirow[b]{2}{*}{.115} & \multirow[b]{2}{*}{$5.269 *$} & 15.019 & .000 \\
\hline & $\begin{array}{c}\text { Dementia } \\
\text { knowledge }\end{array}$ & .031 & .013 & .123 & & & $2.295^{*}$ & .022 \\
\hline
\end{tabular}

${ }^{*} \mathrm{p}<.05, * * \mathrm{p}<.01, * * * \mathrm{p}<.001$

As for the effects of dementia knowledge on caring behavior, statistically significant differences were found in communication: the better the dementia knowledge, the better the communication $(t=3.378$, $\mathrm{p}<0.01)$. Statistically significant differences were found in safety management: the better the dementia 
knowledge, the better the safety management $(t=3.804, p<0.001)$. Statistically significant differences were found in health promotion: the better the dementia knowledge, the better the health promotion $(\mathrm{t}=3.519, \mathrm{p}<0.001)$. Statistically significant differences were found in daily living: the better the dementia knowledge, the better the daily living $(t=2.295, \mathrm{p}<0.05)$. In other words, the better the dementia knowledge care workers had, the better the caring behavior they showed.

\subsection{Test for Effects of Dementia Knowledge on Job Satisfaction}

[Table 7] Effects of Dementia Knowledge on Job Satisfaction

\begin{tabular}{|c|c|c|c|c|c|c|c|c|}
\hline \multirow{2}{*}{$\begin{array}{c}\text { Dependent } \\
\text { variable }\end{array}$} & \multirow{2}{*}{$\begin{array}{l}\text { Independent } \\
\text { variable }\end{array}$} & \multicolumn{2}{|c|}{$\begin{array}{l}\text { Non-standardized } \\
\text { coefficient }\end{array}$} & \multirow{2}{*}{\begin{tabular}{|c|}
$\begin{array}{c}\text { Standardized } \\
\text { coefficient }\end{array}$ \\
Beta \\
\end{tabular}} & \multirow{2}{*}{ R Square } & \multirow{2}{*}{$\mathrm{F}$} & \multirow{2}{*}{$\mathrm{t}$} & \multirow{2}{*}{$\mathrm{p}$} \\
\hline & & B & $\begin{array}{l}\text { Standard } \\
\text { error }\end{array}$ & & & & & \\
\hline \multirow{2}{*}{$\begin{array}{c}\text { Internal } \\
\text { satisfaction }\end{array}$} & (Constant) & 2.727 & .263 & & \multirow[b]{2}{*}{.135} & \multirow[b]{2}{*}{$12.409 * * *$} & 10.365 & .000 \\
\hline & $\begin{array}{c}\text { Dementia } \\
\text { knowledge }\end{array}$ & .155 & .016 & .187 & & & $3.523 * * *$ & .000 \\
\hline \multirow{2}{*}{$\begin{array}{c}\text { External } \\
\text { satisfaction }\end{array}$} & (Constant) & 2.782 & .263 & & \multirow[b]{2}{*}{.112} & \multirow[b]{2}{*}{$4.328 *$} & 10.598 & .000 \\
\hline & $\begin{array}{l}\text { Dementia } \\
\text { knowledge }\end{array}$ & .132 & .015 & .112 & & & $2.080^{*}$ & .038 \\
\hline
\end{tabular}

$* \mathrm{p}<.05, * * * \mathrm{p}<.001$

As for the effects of dementia knowledge on job satisfaction, statistically significant differences were found in internal satisfaction: the better the dementia knowledge, the higher the level of internal satisfaction ( $t=3.523, p<0.001)$. Statistically significant differences were found in external satisfaction: the better the dementia knowledge, the higher the level of external satisfaction $(t=2.080, p<0.05)$. In other words, the better the dementia knowledge care workers had, the more satisfied they were with their job.

\subsection{Test for effects of caring behavior on job satisfaction}

[Table 8] Effects of Caring Behavior on Job Satisfaction

\begin{tabular}{|c|c|c|c|c|c|c|c|c|}
\hline \multirow{2}{*}{$\begin{array}{c}\text { Dependent } \\
\text { variable }\end{array}$} & \multirow{2}{*}{$\begin{array}{l}\text { Independent } \\
\text { variable }\end{array}$} & \multicolumn{2}{|c|}{$\begin{array}{c}\text { Non-standardized } \\
\text { coefficient }\end{array}$} & \multirow{2}{*}{\begin{tabular}{|c}
$\begin{array}{c}\text { Standardized } \\
\text { coefficient }\end{array}$ \\
Beta
\end{tabular}} & \multirow{2}{*}{ R Square } & \multirow{2}{*}{$F$} & \multirow{2}{*}{$\mathrm{t}$} & \multirow{2}{*}{$\mathrm{p}$} \\
\hline & & B & $\begin{array}{c}\text { Standard } \\
\text { error }\end{array}$ & & & & & \\
\hline \multirow{5}{*}{$\begin{array}{c}\text { Internal } \\
\text { satisfaction }\end{array}$} & (Constant) & 1.932 & .305 & & \multirow{5}{*}{.165} & \multirow{5}{*}{$5.928 * * *$} & 6.329 & .000 \\
\hline & $\begin{array}{c}\text { Communicat } \\
\text { ion }\end{array}$ & .210 & .095 & .175 & & & $2.213^{*}$ & .028 \\
\hline & $\begin{array}{c}\text { Safety } \\
\text { management }\end{array}$ & -.064 & .100 & -.053 & & & -.639 & .523 \\
\hline & $\begin{array}{l}\text { Health } \\
\text { promotion }\end{array}$ & .204 & .099 & .160 & & & $2.072^{*}$ & .039 \\
\hline & Daily living & -.008 & .082 & -.007 & & & -.101 & .919 \\
\hline \multirow{3}{*}{$\begin{array}{c}\text { External } \\
\text { satisfaction }\end{array}$} & (Constant) & 1.815 & .303 & & \multirow{3}{*}{.205} & \multirow{3}{*}{$9.972 * * *$} & 5.992 & .000 \\
\hline & $\begin{array}{c}\text { Communicat } \\
\text { ion }\end{array}$ & .271 & .094 & .222 & & & $2.881^{* *}$ & .004 \\
\hline & $\begin{array}{c}\text { Safety } \\
\text { management }\end{array}$ & -.044 & .099 & -.036 & & & -.450 & .653 \\
\hline
\end{tabular}




\begin{tabular}{c|c|c|c|c|c|c|c}
\hline & $\begin{array}{c}\text { Health } \\
\text { promotion }\end{array}$ & .197 & .098 & .152 & & $2.012 *$ & .045 \\
Daily living & .029 & .081 & .025 & & & .358 & .721 \\
\hline
\end{tabular}

As for the effects of caring behavior on job satisfaction, internal satisfaction was significantly and positively affected statistically by communication $(\mathrm{t}=2.213, \mathrm{p}<0.05)$ and health promotion $(\mathrm{t}=2.072$, $\mathrm{p}<0.05$ ): the better the communication and health promotion, the higher the level of internal satisfaction. External satisfaction was significantly and positively affected statistically by communication $(\mathrm{t}=2.881, \mathrm{p}<0.01)$ and health promotion $(\mathrm{t}=2.012, \mathrm{p}<0.05)$ : the better the communication and health promotion, the higher the level of external satisfaction. In other words, the better the communication and health promotion care workers made, the more satisfied they were with their job; however, safety management and daily living had no impact on job satisfaction.

\subsection{Test for Mediating Effects of Caring Behavior on the Impact of Dementia Knowledge on Job Aatisfaction}

The three-step mediating effect inventory developed by Baron and Kenny (1987) was used to analyze the mediating effects of caring behavior on the impact of dementia knowledge on job satisfaction. The existence of mediating effects is confirmed by an independent variable impacting a parameter at the first step and on a dependent variable at the second step. In the third step, the parameter needs to affect the dependent variable when both variables were entered simultaneously. In the third step, complete mediation is confirmed by the independent variable having no impact and partial mediation by decreasing the impact. The Sobel test statistically determined them.

[Table 9] Mediating Effects of Caring Behavior on the Impact of Dementia Knowledge on Job Satisfaction.

\begin{tabular}{|c|c|c|c|c|c|c|c|c|}
\hline \multirow{2}{*}{$\begin{array}{l}\text { Dependent } \\
\text { variable }\end{array}$} & \multirow{2}{*}{$\begin{array}{l}\text { Independent } \\
\text { variable }\end{array}$} & \multicolumn{2}{|c|}{$\begin{array}{c}\text { Non-standardized } \\
\text { coefficient }\end{array}$} & \multirow{2}{*}{\begin{tabular}{|c|}
$\begin{array}{c}\text { Standardized } \\
\text { coefficient }\end{array}$ \\
Beta
\end{tabular}} & \multirow{2}{*}{ R Square } & \multirow{2}{*}{$\mathrm{F}$} & \multirow{2}{*}{$\mathrm{t}$} & \multirow{2}{*}{$\mathrm{P}$} \\
\hline & & B & $\begin{array}{l}\text { Standard } \\
\text { error }\end{array}$ & & & & & \\
\hline \multirow{2}{*}{$\begin{array}{l}\text { Caring } \\
\text { behavior }\end{array}$} & (Constant) & 3.303 & .180 & & \multirow[b]{2}{*}{.142} & \multirow[b]{2}{*}{$14.962 * * *$} & 18.339 & .000 \\
\hline & $\begin{array}{c}\text { Dementia } \\
\text { knowledge }\end{array}$ & .141 & .011 & .205 & & & $3.868 * * *$ & .000 \\
\hline \multirow{2}{*}{$\begin{array}{c}\text { Job } \\
\text { satisfaction }\end{array}$} & (Constant) & 2.754 & .247 & & \multirow[b]{2}{*}{.125} & \multirow[b]{2}{*}{$8.909 * *$} & 11.164 & .000 \\
\hline & $\begin{array}{c}\text { Dementia } \\
\text { knowledge }\end{array}$ & .143 & .015 & .159 & & & $2.985^{* *}$ & .003 \\
\hline \multirow{3}{*}{$\begin{array}{c}\text { Job } \\
\text { satisfaction }\end{array}$} & (Constant) & 1.570 & .336 & & \multirow{3}{*}{.192} & \multirow{3}{*}{$17.315^{* * *}$} & 4.674 & .000 \\
\hline & $\begin{array}{l}\text { Dementia } \\
\text { knowledge }\end{array}$ & .129 & .014 & .105 & & & $1.997 *$ & .047 \\
\hline & $\begin{array}{c}\text { Caring } \\
\text { behavior }\end{array}$ & .359 & .072 & .264 & & & $5.009 * * *$ & .000 \\
\hline
\end{tabular}

$* \mathrm{p}<.05, * * \mathrm{p}<.01, * * * \mathrm{p}<.001$

sobel test : $\mathrm{z}=4.647 * * *$

As for the mediating effects of caring behavior on the impact of dementia knowledge on job satisfaction, dementia knowledge significantly and positively affected caring behavior statistically at the first step $(\mathrm{t}=3.868, \mathrm{p}<0.001)$. Dementia knowledge significantly and positively affected job 
satisfaction statistically at the second step $(\mathrm{t}=2.985, \mathrm{p}<0.01)$. At the third step, caring behavior positively affected job satisfaction $(\mathrm{t}=5.009, \mathrm{p}<0.001)$, and dementia knowledge positively affected job satisfaction $(\mathrm{t}=1.997, \mathrm{p}<0.05)$. The impact of dementia knowledge was weaker at the third step than at the second step. Sobel test found $\mathrm{z}=4.647$, which was statistically significant: caring behavior had partially mediating effects on the impact of dementia knowledge on job satisfaction.

\section{Conclusion}

This study investigated the effects of dementia knowledge on job satisfaction of care workers through the medium of caring behavior. A total of 344 nursing care workers who provide long-term care services through elderly care facilities and home welfare centers in $\mathrm{K}$ and $\mathrm{D}$ regions responded to a questionnaire distributed from December 1 to December 30, 2020. This study obtained the following results:

First, dementia knowledge affected caring behavior. The better the dementia knowledge, the better the communication, safety management, daily living, and health promotion among the sub-factors for caring behavior, which suggests the need for dementia-related education to improve caring behavior.

Second, the better the dementia knowledge care workers had, the more satisfied they were with their job. This finding implies that the better the dementia knowledge, the higher the level of job satisfaction, and the higher the quality of caregiving service for dementia patients; that is, high-quality caregiving service depends on job satisfaction that enables the efficient and positive performance of a job given to individuals, and the outcome of job satisfaction is expected to enhance job performance and contribute to the improvement in the quality of care[17].

Third, caring behavior partially affected job satisfaction in care workers. Communication and health promotion positively affected both internal and external factors for job satisfaction. The better the communication and health promotion care workers made, the more satisfied they were with their job, whereas safety management and daily living had no impact on job satisfaction. It is, therefore, necessary to improve job satisfaction by enhancing caring behavior.

Fourth, caring behavior had partially mediating effects on the impact of dementia knowledge on job satisfaction. The better the dementia knowledge, the higher the quality of care for dementia patients. It is possible to improve caring behavior and job satisfaction with improved dementia knowledge through professional, systematic, and regular education aimed at improving dementia knowledge.

Based on these results, the following suggestions can be made:

It is necessary to introduce an effective education method based on real-life cases of the elderly with dementia and keep the education sustainable in pursuit of better caregiving behavior for the elderly with dementia and a higher level of job satisfaction. Since dementia knowledge is directly connected with job satisfaction and a higher qualitative level of service in care workers, it is, therefore, necessary to make it legally obligatory to give dementia-related education to every care worker, secure professional manpower concerned with dementia, and build a foundation for stable operation of the long-term care insurance system. It is also necessary to make it legally mandatory to give dementiarelated education, which is currently given on a one-time basis, provide supplementary education annually, and make care workers more professional and competent. Better dementia knowledge of care workers may contribute to a qualitative improvement in long-term care insurance service and build the basis for the long-term care insurance system's stable operation. However, this study needs to expand the research subjects to nursing care workers at facility benefit institutions, repeated studies on factors affecting nursing care activities in consideration of various variables, and the region covered in order to generalize the results. 


\section{References}

[1] http://kostat.go.kr/portal/kor, May 30 (2017)

[2] K. W. Kim, J. H. Park, M. H. Kim, M. D. Kim, B, J. Kim, S. K. Kim, J. L. Kim, S. W. Moon, J. N. Bae, J. I. Woo, S. H. Ryu, J. C. Yoon, N. J. Lee, D. Y. Lee, D. W. Lee, S. B. Lee, J. J. Lee, J. Y. Lee, C. U. Lee, S. M. Chang, J. H. Jhoo, M. J. Cho, A Nationwide Survey on the Prevalence of Dementia and Mild Cognitive Impairment in South Korea, Journal of Alzheimers Disease, (2011),Vol.23, No.2, pp.281-291, DOI: https://doi.org/10.3233/JAD-2010-101221

[3] J. P. Kim, M-Y. Hyun, Depression and Suicidal Ideation in Elders with Dementia, Journal Korean Academy of Nursing, (2013), Vol,43, No.2, pp.296-303, DOI: https://doi.org/10.4040/jkan.2013.43.2.296

[4] M. J. Kim, J. Y. Hwang, A Study on the Long-Term Care Insurance System prepare for the Super-Aged Society, Journal of the Korea Academia-Industrial cooperation Society, (2019), Vol.20, No.10, pp.395-405, DOI: 10.5762/KAIS.2019.20.10.395

[5] Y. S. Lee, A Study on the Main Contents and the Point at Issue of the Law of Long-Term Care Insurance for Senior Citizens, Korean Journal of Insurance, (2008), No.79, pp.163-193, UCI: G704-000660.2008..79.006

[6] E. H. Kong, The Effects of Dementia Education Program on Certified Geriatric Caregivers in a Nursing Home, Journal of Korean Academy of Psychiatric and Mental Health Nursing, (2010), Vol.19, No.4, pp.349-358, UCI: G704-001695.2010.19.4.004

[7] T. B. Kim, A Study on the Service Quality Enhancement for the Long-Term Care Insurance, Sang Ji University, Master's thesis, pp.74-80, (2018)

[8] L. Burgess, S. Page, Educating nursing staff involved in the provision of dementia care, Nursing Times, (2003), Vol.99, No.46, pp.34-37.

[9] A. Arai, T. Ozaki, Y. Katsumata, Behavioral and psychological symptoms of dementia in older residents in long-term care facilities in Japan: a cross-sectional study, Aging \& Mental Health, (2017), Vol.21, No.10, pp.1099-1105, DOI: 10.1080/13607863.2016.1199013

[10] http://youtu.be/gc60.kbYg, Oct 3 (2012)

[11] H. J. Kim, H. K. Kim, A Study on the Influences of the Elderly Long-Term Care Worker's Job Stress on the Organizational Effectiveness, Korean Journal of Gerontological Social Welfare, (2011), No.51, pp.191-214, DOI: http://doi.org/10.21194/kjgsw..51.201103.191

[12] S. H. Kim, J. M. Ha, J. H. Shin, The Experience of Long-term Caregiver Education Courses, Journal of Korean Gerontological Society, (2010) Vol.30, No.1, pp.1-20, UCI: G704-000573.2010.30.1.004

[13] S. Iliffe, T. Koch, P. Jain, F. Lefford, G. Wong, A. Warner, J. Wilcock, Developing an educational intervention on dementia diagnosis and management in primary care for the EVIDEM-ED trial, Trials, (2012), Vol.13, No.142, pp.21-23, DOI: $10.1186 / 1745-6215-13-142$

[14] E. H. Kong, The Effects of Dementia Education Program on Certified Geriatric Caregivers in a Nursing Home, Journal of Korean Academy of Psychiatric and Mental Health Nursing, (2010), Vol.19, No.4, pp.349-358, UCI: G704-001695.2010.19.4.004

[15] A. Y. Park, A Study of Knowledge about Dementia, Empathy and Attitudes toward Dementia in Caregivers of Older Adults with Dementia, Journal of Digital Convergence, (2012), Vol.16, No.1, pp.389-397, DOI: https://doi.org/10.14400/JDC.2018.16.1.389

[16] J. S. Kim, The Effect of Dementia Knowledge of Visiting Nursing Care Workers on Job Satisfaction and Work Efficiency, Ajou University, Master's thesis, Ajou University, pp.1-57, (2018)

[17] Noh Jun-hee, Lim Eun-joo, Heo Jeong, The Factors Influencing Careworker's Care Performance for Elders with Dementia, The Korean Journal of Health Service Management, (2012), Vol.6, No.3, pp.75-84, UCI: G704SER000002085.2012.6.3.003

[18] S. H. Kim, H. E. Nam, S. J. Park, Effects of Care workers' Job Satisfaction on the Quality of their Stay-at-Home 
The Effects of Dementia Knowledge on Job Satisfaction of Care Workers: Testing the Mediating Effects of Caring Behavior

aged Welfare Service, The Journal of the Korea Contents Association, (2012),Vol.12, No.4, pp.282291, DOI: 10.5392/JKCA.2012.12.04.282

[19] I. S. Kho, E. K. Han, D. R. Kim, Relationship among Dementia Knowledge, Attitude, and Care Burden of Nurses in Center for Dementia, Journal of the Korea Convergence Society, (2017), Vol.8, No.9, pp.6775, DOI: https://doi.org/10.15207/JKCS.2017.8.9.067 